\title{
The abundance, diversity and distribution of small fishes in mangrove and non-mangrove estuaries in warm temperate South Africa
}

\author{
Steven McGregor, Nadine A. Strydom \\ Department of Zoology, Nelson Mandela University, P.O. Box 77000, Port Elizabeth, 6031 South Africa. \\ (SM) E-mail: s214045560@mandela.ac.za. ORCID iD: http://orcid.org/0000-0002-1061-567X \\ (NAS) (Corresponding author) E-mail: Nadine.Strydom@mandela.ac.za. ORCID iD: http://orcid.org/0000-0003-4292-8678
}

\begin{abstract}
Summary: Mangroves in tropical and subtropical regions have been well documented in terms of the advantages they provide and their role in structuring ichthyofaunal assemblages, but little is known about their warm temperate counterparts. The study aimed to investigate the importance of warm temperate mangroves by comparing the abundance, diversity and distribution of small fishes in mangrove and non-mangrove estuaries in warm temperate South Africa. A $50 \times 2$ m (12-mm mesh) seine net was used over three summer seasons to sample small fishes in the Gonubie, Qora, Nahoon and Xhora estuaries (the latter two being mangrove estuaries). Fish abundance and diversity showed little variation among estuaries, despite the presence of mangroves. Estuaries in warm temperate areas are not only at the edge of mangrove distribution, but also offer alternative habitats which lend similar advantages to fish survival. It appears that warm temperate ichthyofauna have not yet evolved a dependence on mangrove systems in terms of the food, refuge and other ecological services they provide. Understanding the function of habitats and their value in enhancing fish survival in estuarine nursery areas is essential for fish conservation.
\end{abstract}

Keywords: ichthyofauna; estuary usage; juveniles; nursery; recruitment; refuge; pneumatophores.

Abundancia, diversidad y distribución de juveniles de peces en estuarios con y sin manglares en áreas templadas de Sudáfrica

Resumen: El papel de los manglares en la estructuración de las comunidades de peces en regiones tropicales y subtropicales está bien documentado, sin embargo, es poco conocido en las zonas templadas. El estudio investiga la importancia de los manglares de zonas templadas comparando la abundancia, diversidad y distribución de juveniles de peces en estuarios con y sin manglares de Sudáfrica. Se utilizó una red de cerco de $50 \mathrm{~m}$ (12 mm de malla) durante tres veranos para muestrear juveniles de peces en cuatro estuarios: Gonubie, Qora, Nahoon y Xhora (los dos últimos con manglares). La abundancia y diversidad de peces mostró una escasa variación entre estuarios, a pesar de la presencia o ausencia de manglares. Los estuarios de las zonas templadas están en los límites de distribución de los manglares y pueden, además, favorecer la supervivencia de los peces. Estos resultados implicarían que la ictiofauna no ha evolucionado todavía en sistemas de manglares en función de las ventajas (ej. alimento, refugio) que pueden proporcionar estos ecosistemas. El estudio de estos hábitats y su valor como refugio de los juveniles de peces es esencial para la conservación de estas especies.

Palabras clave: ictiofauna; uso de los estuarios; juveniles; guardería; reclutamiento, refugio, pneumatóforos.

Citation/Cómo citar este artículo: McGregor S., Strydom N.A. 2018. The abundance, diversity and distribution of small fishes in mangrove and non-mangrove estuaries in warm temperate South Africa. Sci. Mar. 82(2): 81-93. https://doi. org/10.3989/scimar.04744.31A

Editor: E. Macpherson.

Received: December 11, 2017. Accepted: May 31, 2018. Published: June 8, 2018.

Copyright: () 2018 CSIC. This is an open-access article distributed under the terms of the Creative Commons Attribution 4.0 International (CC BY 4.0) License.

\section{INTRODUCTION}

Mangroves are distributed throughout the tropical regions of the globe, where their distribution is re- stricted to the $20^{\circ} \mathrm{C}$ winter seawater isotherm in both the southern and northern hemispheres (Duke 1993). In the southern hemisphere, mangroves extend further southward on the eastern sides of continents into warm 
temperate climatic regions (Hogarth 2015). These warm, temperate mangrove stands typically contain fewer species (sometimes only a single species) than stands in the tropics (Hogarth 2015). The complex prop-roots and pneumatophores of mangrove trees form a solid substrate within the intertidal and subtidal zones in estuaries, where they provide suitable habitat for a wide diversity of other floral and faunal life (Ellison and Farnsworth 1992).

Mangrove forests are considered one of the most productive of all marine and coastal ecosystems (Duarte and Cebrian 1996), contributing high levels of nutrients into estuarine ecosystems through detrital food chains starting with the decomposition of leaf litter (Nagelkerken et al. 2008). Kristensen et al. (2008) noted that detritus from mangroves and benthic microalgae are typically the greatest contributors to autochthonous carbon sources in tropical estuarine ecosystems. This high nutrient input, coupled with the refuge and habitat which mangrove forests provide, lends an explanation for the high abundance and diversity of fishes associated with mangrove estuaries (Laegdsgaard and Johnson 2001, Blaber 2007).

Mangroves form a vital component in the life history of many fish species in both tropical and subtropical regions (Mahesh and Saravanakumar 2015). Up to $30 \%$ of commercial fishery species globally have been found to be dependent on mangroves (Naylor et al. 2000), which produced a total annual catch of approximately 30 million $\mathrm{t}$ in 2002 (FAO 2004). In the Gulf of California fishery catches have been positively related to the abundance of nearby mangroves, which are utilized by numerous fishery species as a nursery and feeding area (Aburto-Oropeza et al. 2008). Mumby et al. (2004) also found that the biomass of important commercial fishery species is more than doubled when mangroves are utilized at some point in the fish's life cycle. Numerous studies show similar findings, asserting that mangroves play a crucial role in sustaining production in fisheries (for example, see Rönnbäck 1999, Manson et al. 2005, Aburto-Oropeza et al. 2008). This typically forms the foundation for any management decisions with regard to the conservation and reestablishment of mangrove stands, as well as other important coastal wetland habitats (Manson et al. 2005). Commercially important fish species commonly found utilizing mangroves as a nursery habitat include, among others, snappers (Lutjanus spp.), barracuda (Sphyraena barracuda), mullets (Chelon and Mugil spp.), groupers (Epinephelus spp.) and catfish (Arius and Tachysurus spp.) (Rönnbäck 1999, Lugendo et al. 2005).

Despite their economic and ecological importance, mangroves are under threat globally. Approximately $90 \%$ of mangroves occur in developing countries, where they are critically endangered and on the brink of local extinction in 26 known countries (Kathiresan 2008). Experts suggest that ecosystem services offered by mangroves may be lost within the next century (Kathiresan 2008). Threats to mangroves include habitat clearing for aquaculture and development, harvesting of wood for fuel and timber, hydrological al- terations within estuaries, pollution and climate change (Alongi 2002, Gilman et al. 2008).

In South Africa, mangroves are restricted to the eastern coastline and can be found in 37 estuaries covering almost 1700 ha (Adams et al. 2004). Dominant mangrove species in South Africa include the white mangrove (Avicennia marina), the black mangrove (Bruguiera gymnorrhiza) and the red mangrove (Rhizophora mucronata), with the former extending to the southeastern warm temperate coast (Macnae 1963). The southeastern coast forms home to the majority of mangrove estuaries in South Africa, and the lack of infrastructure and scientific knowledge in the region makes conservation and management of this habitat type difficult.

The role of mangroves in warm temperate regions remains relatively unstudied in terms of the advantages they provide (including a refuge/nursery habitat for larval- and juvenile-stage fishes and feeding opportunities). It is therefore important to investigate the role of warm temperate mangroves for fishes utilizing estuaries as nursery areas, especially since these vegetation types are under threat. This knowledge of ecosystem value will help to enable the proper conservation of habitats for fishes. The aim of the study was to investigate catches of juvenile and small adult fishes during the peak summer recruitment period in mangrove and non-mangrove estuaries to determine whether differences in catches exist, and whether mangrove presence lends an advantage to fish survival in warm temperate South Africa. It was hypothesized that mangrove estuaries would have a greater abundance and diversity of young fishes than non-mangrove estuaries.

\section{MATERIALS AND METHODS}

\section{Study site}

Four estuaries (Nahoon, Gonubie, Qora and Xhora), all of which drain into the Indian Ocean, were selected within the warm temperate region of the Eastern Cape, South Africa (Fig. 1). Estuarine selection was based on similar geomorphological and biological features: All four estuaries had permanently open mouths and similar drainage basin areas, river and estuary sizes, and available habitats. The Nahoon Estuary $\left(32^{\circ} 59^{\prime} \mathrm{S}\right.$; $27^{\circ} 57^{\prime} \mathrm{E}$ ) is situated furthest south of the four estuaries sampled, and falls on the edge of the southern limit of mangrove distribution in Africa (Quisthoudt et al. 2013). Three mangrove species have been introduced into the Nahoon Estuary from Durban Bay since 1969, including the white, black, and red mangroves (Saintilan et al. 2014, Hoppe-Speer et al. 2015). The Gonubie Estuary $\left(32^{\circ} 56^{\prime} \mathrm{S}, 28^{\circ} 02^{\prime} \mathrm{E}\right)$ is situated $10 \mathrm{~km}$ to the east of Nahoon Estuary and can be found north of the city of East London. The Gonubie Estuary is relatively similar to the Nahoon Estuary in terms of watershed size and available habitat, but there are no mangroves in the Gonubie Estuary. The Nahoon and Gonubie estuaries are situated within urban development areas, and this has led to the anthropogenic alteration of both systems. Whitfield and Baliwe (2013) described both the health 


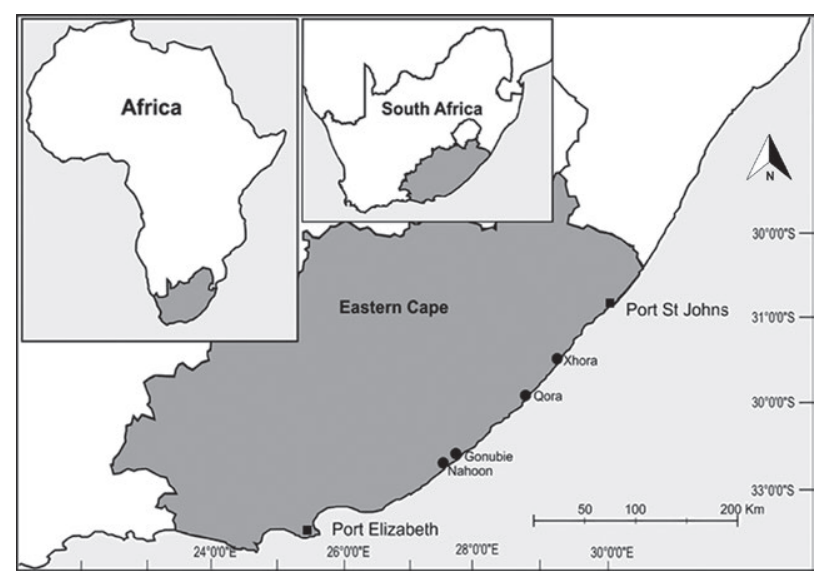

Fig. 1. - Geographical locations of the four estuaries sampled on the south eastern coast of warm temperate South Africa.

and condition of the Nahoon Estuary as fair, and the same parameters of the Gonubie Estuary as good. The Qora Estuary $\left(32^{\circ} 27^{\prime} \mathrm{S}, 28^{\circ} 40^{\prime} \mathrm{E}\right)$ is situated approximately $80 \mathrm{~km}$ northeast of Gonubie Estuary, and the literature shows no historical evidence of mangroves in this estuary (Ward and Steinke 1982). The Xhora Estuary $\left(32^{\circ} 10^{\prime} \mathrm{S}, 29^{\circ} 00^{\prime} \mathrm{E}\right)$ lies north of the Qora Estuary, roughly $290 \mathrm{~km}$ northeast of East London, forming the northern boundary of this study. A number of mangrove stands are present in the lower reaches of the Xhora Estuary (Ward and Steinke 1982). The Qora and Xhora estuaries are located along the rural Wild Coast (formerly Transkei), where infrastructure and development are lacking, so humans have little impact on these estuaries. However, due to poverty and lack of management in the region, mangrove and salt marsh habitat are often cut down for wood and grazed by livestock. Whitfield and Baliwe (2013) described the Qora and Xhora estuaries as being in excellent and good condition respectively, and the health of both estuaries as good.

\section{Data collection}

Field sampling took place over a three-year period from 2015 to 2017 , with data collected over the firstquarter moon phase in January of each year. Prior to sampling, five fixed sites were chosen remotely along the length of each estuary and marked using a GPS. Sites were spaced at one-kilometre intervals, with the first site being situated approximately $500 \mathrm{~m}$ from each estuary mouth. Physico-chemical measurements including temperature $\left({ }^{\circ} \mathrm{C}\right)$, turbidity (NTU), salinity (PSU), conductivity $\left(\mathrm{S} \mathrm{m}^{-1}\right), \mathrm{pH}$, dissolved oxygen $\left(\mathrm{mg} \mathrm{L}^{-1}\right)$, and total dissolved solids were measured at each site using a YSI-6600 multimeter. Habitat type was also recorded at each site based on sediment and vegetation type. Six different habitat types were identified, including mud, mud and mangrove, mud and rock, mud and Nanozostera, sand, and sand and mangrove. Habitat types in the upper reaches of each estuary were characteristically muddy and rocky, while the lower $2 \mathrm{~km}$ were mostly sand. The middle reaches were mostly muddy, with mangroves present in the Nahoon and Xhora estuaries and absent in the Gonubie and Qora estuaries.
Small fishes were sampled at each site using a $50 \times 2 \mathrm{~m}$ seine net with a $12-\mathrm{mm}$ stretched mesh. The seine net was deployed from a boat and pulled ashore, covering an estimated area of $400 \mathrm{~m}^{2}$. A consistent deployment of the seine net was maintained at each site, while a heavy sinker line allowed the net to be dragged through eelgrass (Nanozostera capensis) beds and over the pneumatophores of mangroves in order to obtain quantifiable results among sites and estuaries.

All fishes were identified in situ to the species level, measured (in millimetres) and quantified prior to being released back into the estuary. Individuals which could not be identified in the field were placed in sample jars containing a $10 \%$ formalin solution for further identification in the laboratory. Fishes were identified in the laboratory by doing lateral line scale counts, as well as teeth counts for Mugilidae species following van der Elst and Wallace (1976). Once identified, all fishes were categorized into estuarine usage guilds following Potter et al. (2015), with categorization determined following Whitfield (1994b).

\section{Statistical analyses}

Prior to statistical analyses, all factors were tested for normality and homogeneity of variance using the Shapiro-Wilk test and Levene test, respectively. Of the environmental variables, temperature and dissolved oxygen met the assumptions of normality and homogeneity of variance, and so did turbidity after square-root transformation. Therefore, parametric tests (one-way ANOVA and Tukey test) were used for these variables. The remaining environmental variables did not meet parametric assumptions, even after transformation, so non-parametric tests were used. The Kruskal-Wallis test was used to compare non-parametric environmental variables among years, estuaries, sites and habitats. The Mann-Whitney test was then used to further explore the data if the Kruskal-Wallis test returned a significant $p$-value $(p<0.05)$. The Bonferroni Correction was applied for post hoc use of Mann-Whitney tests at a 0.025 level of significance.

Catch data were separated into marine and estuarine usage guilds, which were analysed independently to avoid any confounding effects of different estuary use by fishes that are resident versus immigrant. Fish communities were explored using diversity indices (Margalef species richness and Shannon-Wiener diversity) in PRIMER v.6 (Clarke and Gorley 2006). Catch data did not meet the assumptions of parametric tests, so non-parametric tests were used. The Kruskal-Wallis and Mann-Whitney tests were used to compare species richness, abundance and diversity among years, estuaries, sites and habitats.

Generalized additive models were used to explore trends of species richness, abundance and diversity in relation to physico-chemical variables, as well as the influence that mangrove presence or absence and habitat type had on the same catch parameters. Catch data of fishes from each guild and of dominant species were added to the generalized additive models using a negative binomial distribution with log link. Rare 
84 - S. McGregor and N.A Strydom

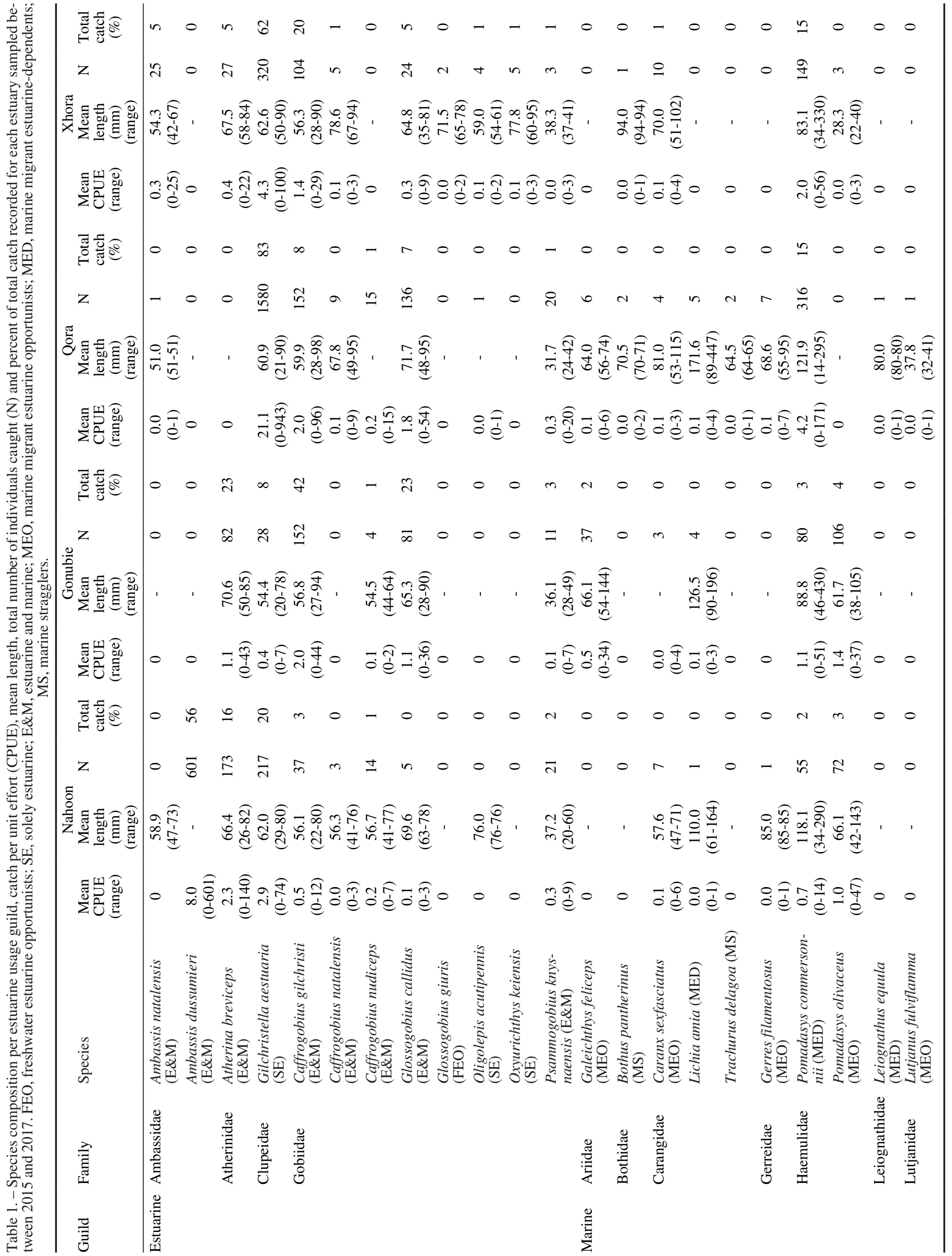




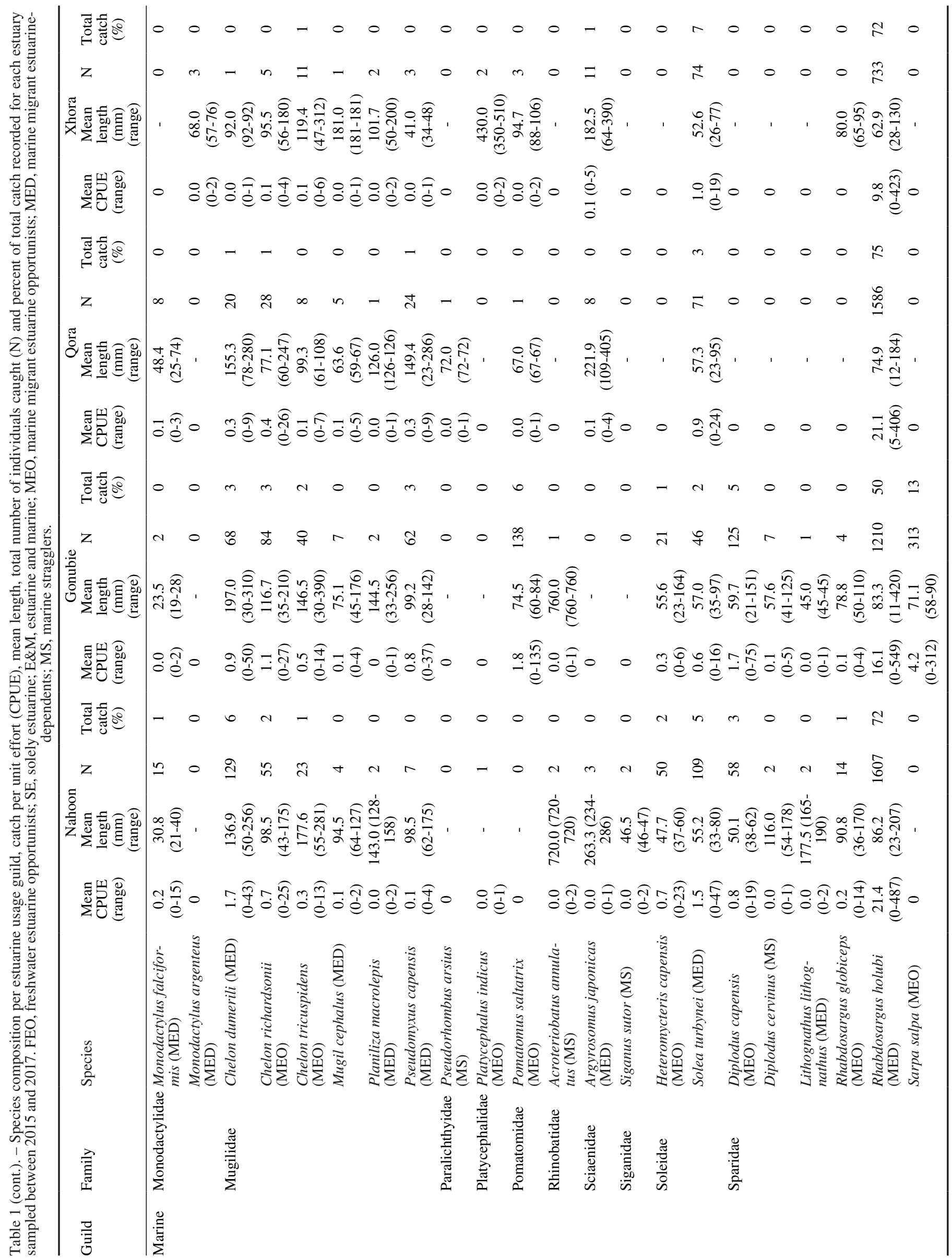




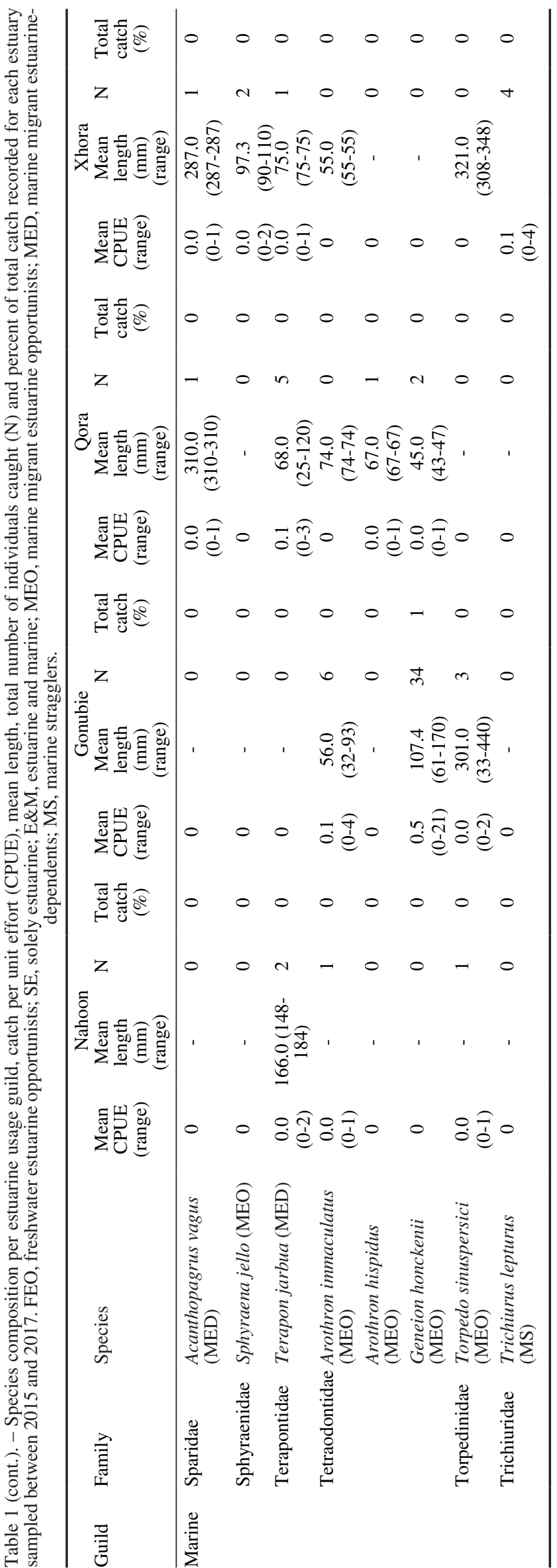

species were removed from the model. The physicochemical variables for each GAM were determined using forward stepwise variable selection. When habitat type was added to the model, dispersion was tested with 'dispersiontest' by Cameron and Trivedi (1990). A Poisson distribution with log link was used when there was under-dispersion and a Quasi-poisson distribution with log link when there was over-dispersion. The Akaike information criterion was used to select the model with the best fit. Statistical analyses were conducted using R and RStudio (R Core Team 2017) with the packages $m g c v, V E G A N$, and ggplot2 (Wickham 2009, Wood et al. 2016, Oksanen et al. 2017).

\section{RESULTS}

\section{Environmental variability}

Within estuaries, horizontal physico-chemical variables exhibited a relatively uniform gradient (Fig. 2). Temperature in the Gonubie Estuary was the only variable with significant variability among sites, with upper sites (Sites 1 and 2) being significantly warmer than lower sites nearest the mouth (Sites 4 and 5) $(p<0.05)$.

Among the estuaries, the variables temperature, salinity, $\mathrm{pH}$ and dissolved oxygen varied significantly, though all four estuaries shared a similar climate regime due to their geographical location. Mean temperatures were significantly warmer in the more northern (Qora and Xhora) estuaries than in the Gonubie Estuary in the south of the study area $(p<0.01)$. Mean salinity varied significantly between the Nahoon and Qora estuaries, as well as between the Gonubie and Qora estuaries $(p<0.025)$, with the Nahoon and Gonubie estuaries exhibiting a more uniform mean salinity gradient throughout the sites sampled. The Xhora Estuary had a significantly higher mean $\mathrm{pH}$ than the remaining three estuaries $(p<0.025)$. Mean dissolved oxygen $\left(\mathrm{mg} \mathrm{L}^{-1}\right)$ was only significantly higher in the Qora Estuary than in the the Nahoon Estuary $(p<0.025)$. Physico-chemical variations in these parameters were also evident inter-annually among estuaries $(p<0.025)$.

\section{Species composition and estuary association}

Over the three-year study period, a total of 11625 fishes were caught among all four estuaries sampled, including fishes from both the marine and estuarine guilds. Catches consisted of 52 taxa represented by 26 families, with only 17 taxa making up $97 \%$ of the total catch (Table 1). The most speciose families were Gobiidae, Mugilidae and Sparidae, which were comprised of eight, seven and six species respectively. The marine guild made up $67 \%$ of the overall catch, representing 7763 individuals from 40 taxa. The estuarine guild had a lower overall abundance and species richness, comprised of 3862 individuals from 12 taxa. Rhabdosargus holubi was the most abundant species, with a total of 5136 individuals captured, accounting for $44 \%$ of the overall catch. Gilchristella aestuaria was the second most abundant species, with 2145 individuals accounting for $18 \%$ of the catch. 

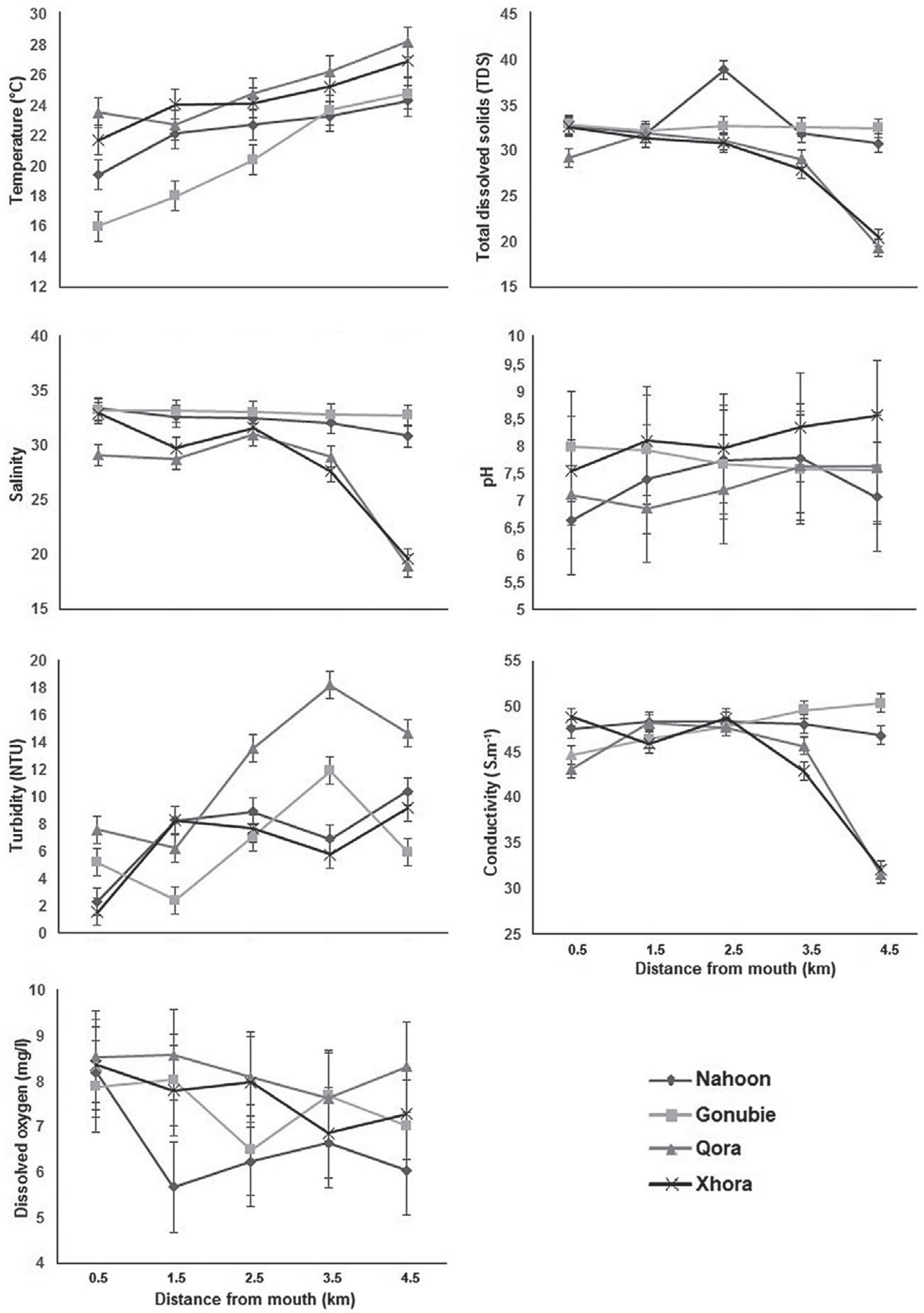

Fig. 2. - Environmental variables averaged over 2015-2017 per site within each of the four estuaries sampled (bars=range). 


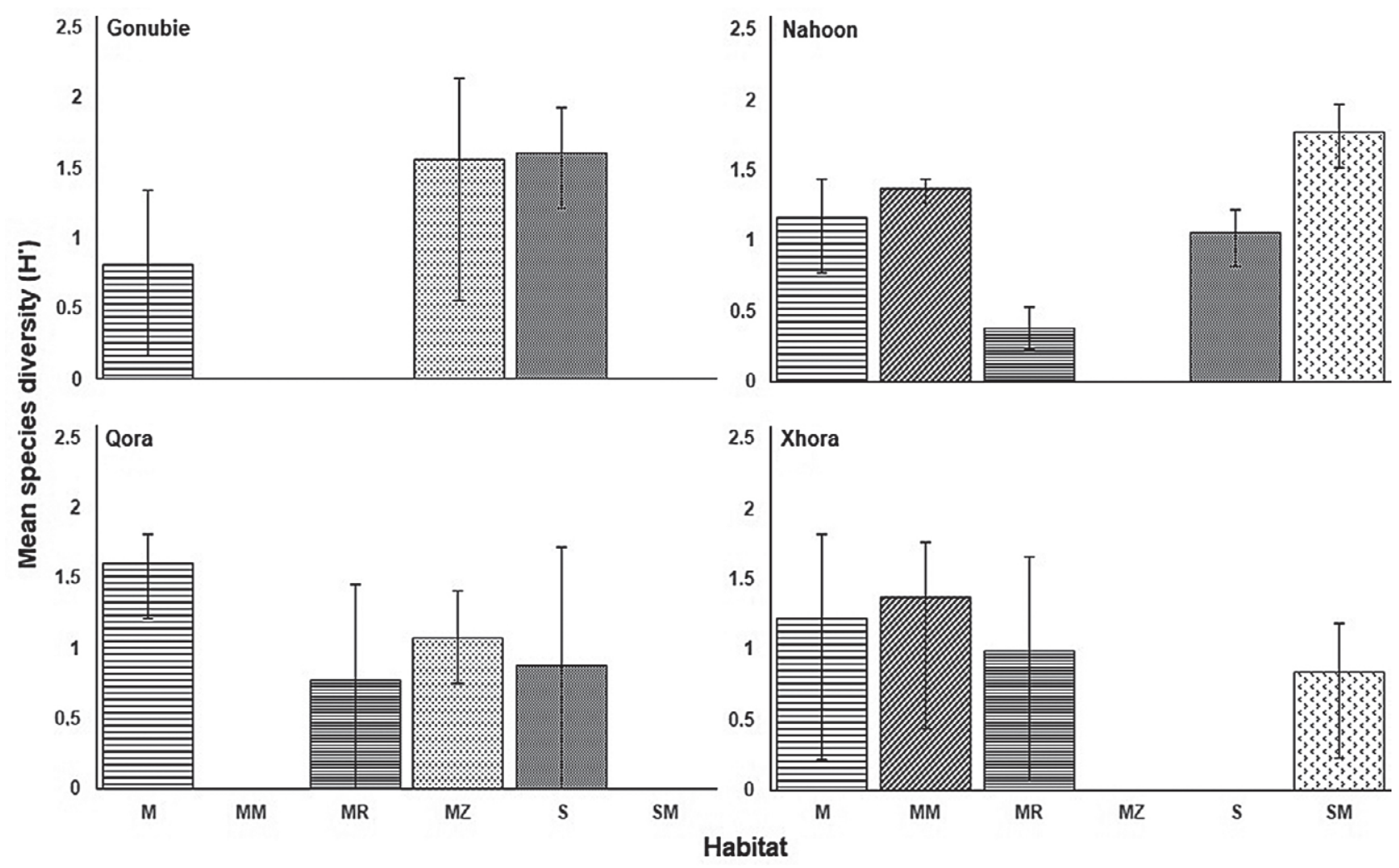

Fig. 3. - Mean species diversity (H') in each habitat type between 2015 and 2017. Gonubie and Qora estuaries: mangroves absent; Nahoon and Xhora estuaries: mangroves present. M, mud; MM, mud and mangrove; MR, mud and rock; MZ, mud and Nanozostera; S, sand; SM, sand and mangrove (bars=range).

Within the estuarine guild, significant differences in size were recorded among estuaries for $G$. aestuaria and Glossogobius callidus. The mean size of G. aestuaria caught in the Gonubie Estuary was significantly smaller (54.4 $\mathrm{mm}$ mean length) than that of those caught in the Nahoon, Qora and Xhora estuaries $(p<0.01)$, which had mean lengths of 62.0, 60.9 and $62.6 \mathrm{~mm}$, respectively. The mean size of $G$. callidus individuals caught in the Qora Estuary was significantly larger $(71.7 \mathrm{~mm}$ mean length) than that of individuals caught in both the Gonubie and Xhora estuaries $(p<0.01)$, which had mean lengths of 65.3 and $64.8 \mathrm{~mm}$, respectively.

In the marine guild, significant differences in length were recorded for Pomadasys commersonnii, the mugilids Chelon dumerili, $C$. richardsonii and $C$. tricuspidens, and $R$. holubi. The largest mean size of $P$. commersonnii was recorded in the Qora Estuary $(121.9 \mathrm{~mm})$ and the smallest in the Xhora Estuary $(83.1 \mathrm{~mm})$. Within the Mugilidae, similar size ranges were recorded in all the estuaries sampled. The largest mugilid species was $C$. dumerili, with the greatest mean length being recorded in the Gonubie Estuary $(197.0 \mathrm{~mm})$. The smallest mean length of a mugilid species (C. richardsonii) was recorded in the Qora Estuary $(77.1 \mathrm{~mm})$. The mean size of the dominant sparid $R$. holubi was greatest in the Nahoon Estuary $(86.2 \mathrm{~mm})$, followed by the Gonubie Estuary $(83.3$ $\mathrm{mm})$, with the Xhora Estuary having the smallest mean size $(62.9 \mathrm{~mm})$.

\section{Fish community composition and habitat use}

Species diversity showed a decreasing trend from the mouth towards the upper reaches within each estuary, but there were no significant differences among estuaries or among habitats (Fig. 3). The Gonubie Estuary had the greatest species diversity $\left(H^{\prime}=1.4\right)$ and the Qora Estuary the lowest $\left(\mathrm{H}^{\prime}=1\right)$. The Gonubie Estuary also had the highest mean species richness (ten species), closely followed by the Nahoon Estuary (nine species). The Qora and Xhora estuaries both had a mean species richness of seven species.

Nahoon Estuary had the greatest habitat complexity at the sites sampled, with a total of five different habitat types. The Qora and Xhora estuaries each had four recorded habitat types, while the Gonubie Estuary showed the lowest habitat complexity with only three habitat types. The sand and mangrove habitat in the Nahoon Estuary had the greatest mean species diversity $\left(H^{\prime}=1.8\right)$, followed by the sand and mud habitats in the Gonubie and Qora estuaries, respectively $\left(H^{\prime}=1.6\right)$. Mud habitat had the most consistently high mean species diversity across all four estuaries sampled.

There was no significant difference in the catch per unit effort (CPUE) of fishes within both the estuarine and marine guilds among habitat types (Fig. 4). Marine species, especially the marine estuarine-dependents, exhibited a high degree of habitat plasticity and dominated the catch throughout all habitat types. Fishes classified within the estuarine and marine category, as well as solely the estuarine category, also displayed habitat 


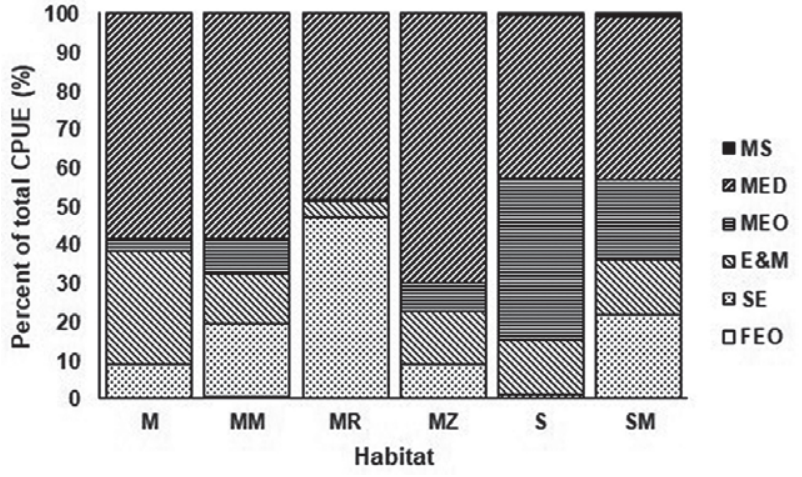

Fig. 4. - Percentage of total catch per unit effort (CPUE) per guild recorded in each habitat type (2015-2017). M, mud; MM, mud and mangrove; MR, mud and rock; MZ, mud and Nanozostera; S, sand; SM, sand and mangrove. FEO, freshwater estuarine opportunists; SE, solely estuarine; E\&M, estuarine and marine; MEO, marine migrant estuarine opportunists; MED, marine migrant estuarinedependents; MS, marine stragglers.

plasticity throughout the habitats sampled. Marine stragglers and marine estuarine opportunists were more abundant in the lower reaches of the estuaries sampled, where the sand habitat was predominant, than further upstream, where mud and rocks were predominant.

The habitats contributing the highest percentage of the total CPUE (combining fishes from all guilds) included mud and Nanozostera (26.5\%), mud and rock $(25 \%)$ and mud $(21.1 \%)$. Mangrove habitats made little contribution to the total CPUE, with the mud and mangrove and sand and mangrove habitats contributing only $7.6 \%$ and $4.6 \%$, respectively, to the overall CPUE combining fishes across all guilds.

When the CPUE of dominant species from the estuarine guild was compared between habitat type, it was found that mud and rock habitat contributed the highest percentage of the overall CPUE of dominant species $(13 \%)$, followed by mud $(8 \%)$ and mud and Nanozostera (6\%) (Fig. 5A). Dominant fishes from the estuarine guild exhibited habitat plasticity, barring $A$. dussumieri, which can be explained by a single, large capture event at one site in the Nahoon Estuary.

Within the marine guild, mud and Nanozostera habitat contributed the highest CPUE of dominant species (19\% overall), followed by the mud and sand habitats, which each contributed $13 \%$, closely followed by the mud and rock habitat, which contributed 12\% (Fig. 5B). Dominant marine species also displayed a high degree of habitat plasticity, although the majority of marine species were recorded at habitats nearest to the mouth of the four estuaries sampled. These habitats included sand, and habitats with mangroves in the two respective mangrove estuaries. Fewer marine species were found further upstream, which was characterized by habitats of mud or the combination of mud and rock.

\section{Relationship between fish abundance and environ- mental variables}

Generalized additive models were used to explore the influence of physico-chemical parameters and habitat type on species distributions. The presence of mangroves was included as a factor in all generalized additive models. The response variables analysed were species richness of all taxa and within guilds, as well as the abundance of dominant species. Species diversity was excluded from the models due to the high similarity among estuaries and habitat types.

The abundances of fishes within the marine guild were best described by a model using conductivity (Table 2 and Fig. 6). Peaks in species abundance were observed at conductivities between 41 and $48 \mathrm{~S} \mathrm{~m}^{-1}$ for species in the marine guild. The model that best fitted the abundance of fishes from the estuarine guild included temperature, salinity, dissolved oxygen and habitat type. Peaks in abundance for the estuarine guild were observed between temperatures of $22^{\circ} \mathrm{C}$ and $24^{\circ} \mathrm{C}$, with a smaller peak occurring at $26.5^{\circ} \mathrm{C}$. Within the same model, there was a peak in abundance
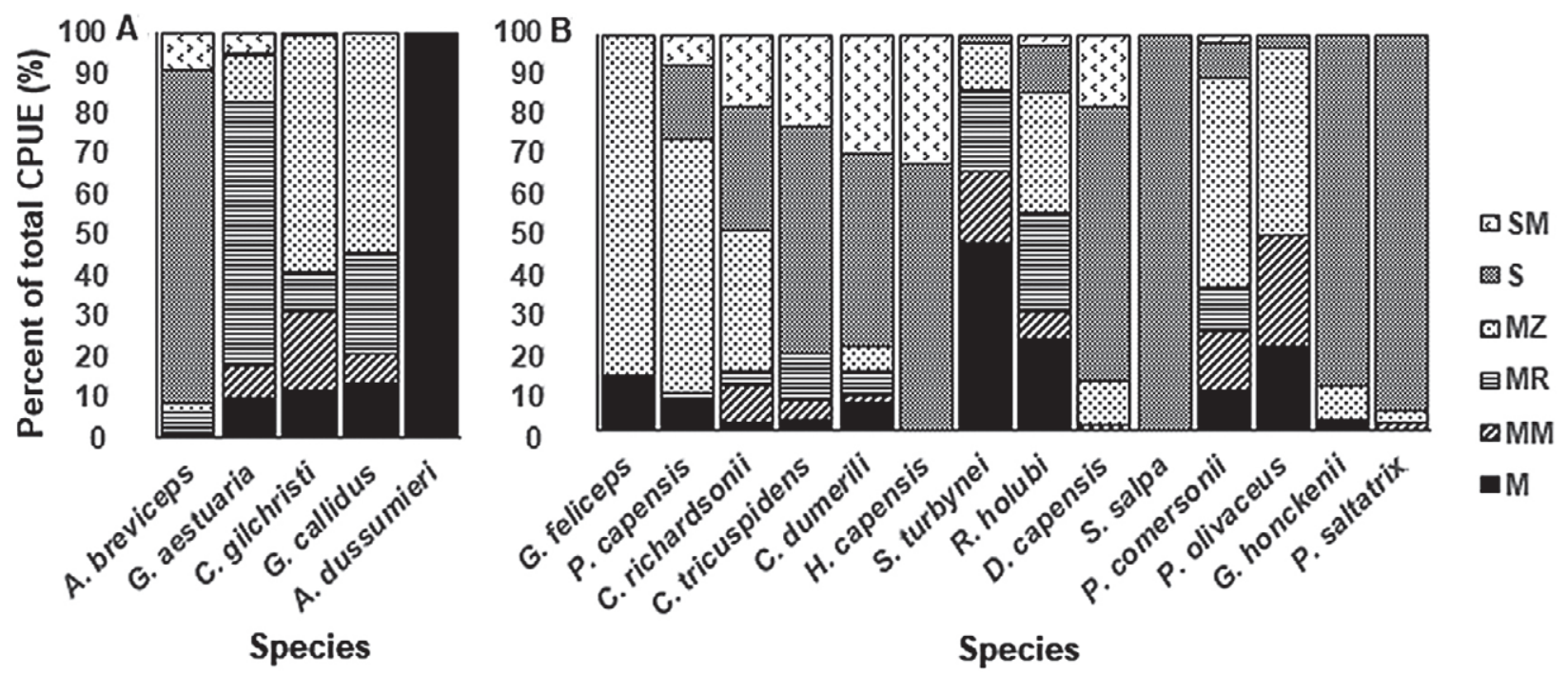

Fig. 5. - Percentage of total catch per unit effort (CPUE) of dominant species recorded in each habitat type (2015-2017). A, estuarine species; $\mathrm{B}$, marine species. M, mud; MM, mud and mangrove; MR, mud and rock; MZ, mud and Nanozostera; S, sand; SM, sand and mangrove. 
Table 2. - Generalized additive model outputs for abundance data of fishes from all taxa, per guild and for dominant species recorded in all estuaries sampled between 2015 and 2017. Temp, temperature $\left({ }^{\circ} \mathrm{C}\right)$; NTU, turbidity; sal, salinity; DO, dissolved oxygen (mg L $\left.{ }^{-1}\right)$; TDS, total dissolved solids; con, conductivity; hab, habitat type. (Significance codes $* * * p<0.001 ; * *<0.01 ; *<0.05$ ).

\begin{tabular}{|c|c|c|}
\hline Grouping (no. species) & Deviance explained (\%) & Significant variable(s) \\
\hline \multicolumn{3}{|l|}{ Abundance } \\
\hline All taxa (52) & 31.1 & con* \\
\hline Estuarine (12) & 65.1 & temp* sal** hab*** \\
\hline Marine (30) & 17.5 & $\operatorname{con}^{* *}$ \\
\hline \multicolumn{3}{|l|}{ Dominant species } \\
\hline Atherina breviceps & 70.6 & temp** DO** hab*** \\
\hline Gilchristella aestuaria & 79.4 & temp*** sal*** DO*** hab*** \\
\hline Caffrogobius gilchristi & 68.1 & NTU** TDS* \\
\hline Pomadasys commersonnii & 65.9 & temp*** sal*** hab* \\
\hline Pomadasys olivaceus & 44.5 & $\mathrm{sal}^{*}$ \\
\hline Chelon dumerili & 63.7 & temp** sal*** \\
\hline Chelon richardsonii & 75.6 & $\operatorname{con}^{*}$ \\
\hline Chelon tricuspidens & 13.4 & temp* \\
\hline Pseudomyxus capensis & 81.5 & temp*** $\mathrm{sal}^{* *}$ \\
\hline Solea turbynei & 74.2 & NTU*** DO *** hab** \\
\hline Diplodus capensis & 23.3 & $\mathrm{sal}^{* *}$ \\
\hline Rhabdosargus holubi & 14.5 & temp** \\
\hline
\end{tabular}
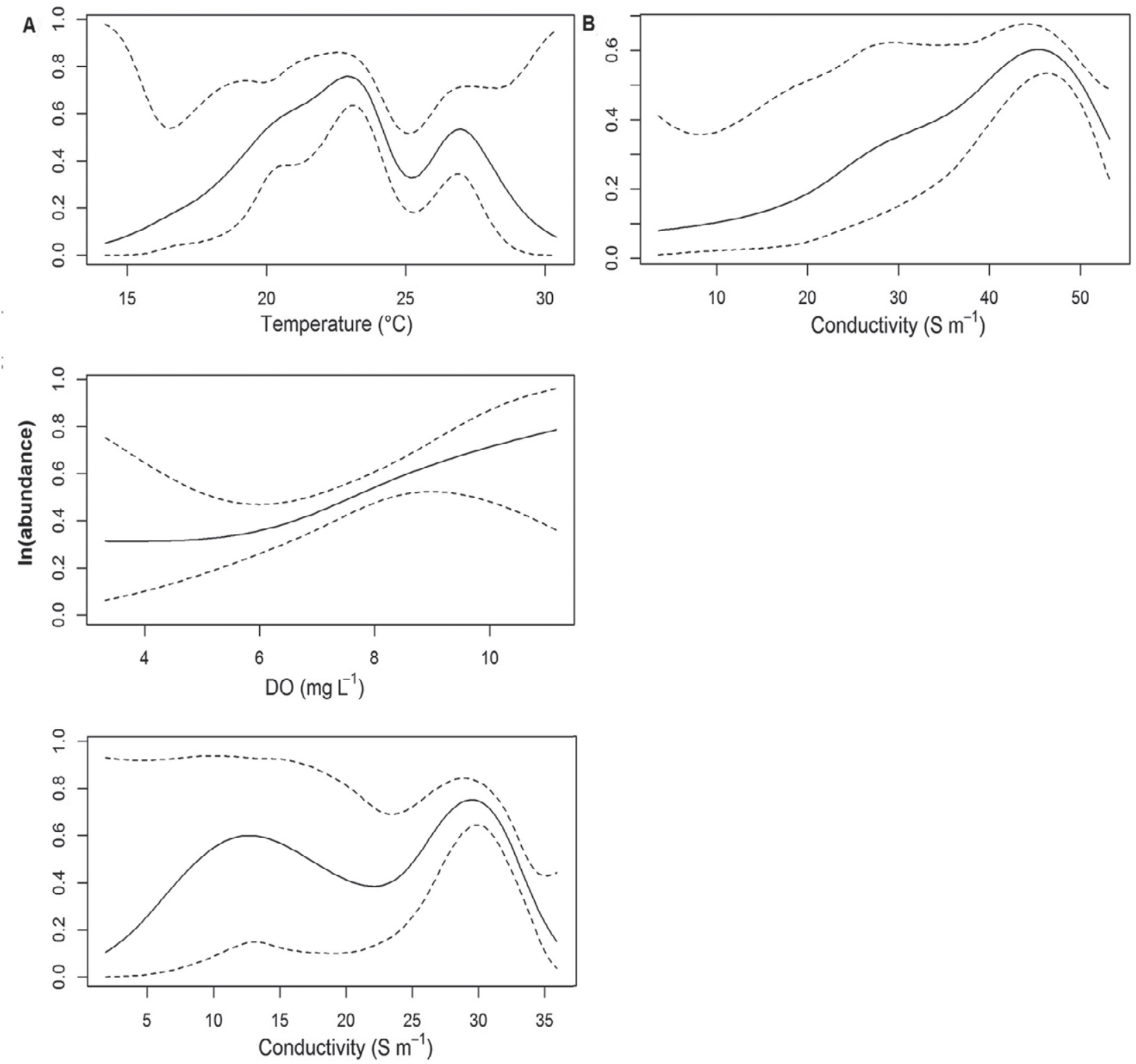

Fig. 6. - Relationships between fish abundance and environmental variables in all estuaries sampled over the period 2015-2017. GAM output plots include estuarine fish abundance (A) and marine fish abundance (B), and correspond to the results in Table 2. 
between conductivity readings of 29 and $31 \mathrm{~S} \mathrm{~m}^{-1}$, with a smaller peak between 10 and $15 \mathrm{~S} \mathrm{~m}^{-1}$. Although dissolved oxygen was not significant in the model, abundance was shown to increase with increasing dissolved oxygen concentrations.

For the dominant species within the estuarine guild, the abundance of Atherina breviceps was best explained by models incorporating temperature, dissolved oxygen and habitat. For $G$. aestuaria, a model with temperature, salinity, dissolved oxygen and habitat best explained abundance, while a model including turbidity and total dissolved solids best explained $C$. gilchristi abundance. Within the marine guild, temperature and salinity were significant variables influencing the abundances of $P$. commersonnii, $C$. dumerili and Pseudomyxus capensis. Temperature also influenced abundances of $C$. tricuspidens and $R$. holubi, while salinity had an impact on $P$. olivaceus and D. capensis. Habitat type also affected the abundances of both $P$. commersonnii and $S$. turbynei, the latter of which was also influenced by turbidity and dissolved oxygen. $C$. richardsonii was the only species for which conductivity had the greatest influence on abundance.

\section{DISCUSSION}

The study aimed to investigate the importance of mangroves for small fishes in warm temperate South Africa. This was the first study of its kind in the region, and it was unknown whether mangroves play an important role in structuring fish communities as their tropical and subtropical counterparts do. Physicochemical variables measured showed little variation among the four estuaries sampled, because the estuaries fall within the same climatic region (Whitfield and Baliwe 2013). There was low variation in species abundance and diversity between mangrove and nonmangrove estuaries for fishes from both the estuarine and marine guilds. Therefore, the hypothesis that mangrove estuaries would have a greater abundance and diversity of young fishes than non-mangrove estuaries is rejected. Generalized additive models indicated that temperature, conductivity and dissolved oxygen were the most important variables structuring the abundance and distribution of fishes from the estuarine guild, while conductivity was the most important for fishes from the marine guild.

The regulation of freshwater flow into estuaries has been identified as a potential threat to estuarine ecosystem structure and function, and to the productivity of fisheries in particular (Saintilan and Wen 2012). Both the Gonubie and Nahoon estuaries had lower freshwater input due to water abstraction and the presence of dams, weirs and causeways along their rivers than the Qora and Xhora estuaries (Wiseman et al. 1993, Whitfield and Baliwe 2013). This reduced freshwater input in the Gonubie and Nahoon estuaries could explain the greater intrusion of marine fishes in these two estuaries, which is indicated by the higher species richness and diversity of fishes from the marine guild. These findings differ from those of Whitfield (1994a) and Pattrick and Strydom (2014), who recorded greater densities of larvae and juvenile marine fishes in more turbid estuaries with a higher freshwater input and moderate to high axial salinity gradients in studies conducted in warm temperate South African estuaries.

Beck et al. (2001) assert that environmental processes functioning in nursery habitats need to provide greater contributions to juvenile survival and adult recruitment from a combination of the following four factors: growth, density, juvenile survival and migration to adult habitats. Mangrove stands are associated with high abundance and diversity of fishes and have the well-known function of forming essential fish nurseries in estuaries (Robertson and Duke 1987, Laegdsgaard and Johnson 1995, Mumby et al. 2004), because they contribute to the four factors mentioned above by Beck et al. (2001). According to Whitfield (2017), different juvenile fish assemblages are supported within different aquatic plant habitats, with some fish species selecting a particular habitat when given a choice of nursery areas within an estuary. However, when a particular preferred nursery area is not present within a system, juveniles will have to use another littoral habitat or move elsewhere. For example, some marine estuarine-dependents such as the flathead mullet (Mugil cephalus) are able to use nearshore coastal waters as alternative nurseries to estuaries (Lenanton and Potter 1987). The flathead mullet has a strong propensity to enter estuaries, but can also make use of coastal waters as a nursery habitat in regions where estuaries are absent and still recruit significant numbers of individuals into adulthood (Lenanton and Potter 1987).

Although numerous studies note that the abundance and diversity of fishes is greater in mangrove habitats in tropical areas (Robertson and Duke 1987, Nagelkerken et al. 2001), additional literature suggests that other habitats within estuaries also account for high abundance and diversity of fishes, while offering similar nursery functions as mangroves. For example, some studies have shown that seagrass beds, salt marshes and reed beds have an important nursery function for fishes while also providing feeding opportunities (Beck et al. 2001, Nagelkerken et al. 2002). The presence of alternative habitat types in the four estuaries sampled may therefore be a possible explanation for the low variation in species abundance and diversity between mangrove and non-mangrove estuaries. All estuaries had eelgrass (Nanozostera capensis) beds, which Paterson and Whitfield (1997) identified as an important feeding area for fishes in the Kariega Estuary in South Africa. Weerts and Cyrus (2002) also found that eelgrass beds actually support a higher abundance and diversity of fishes than neighbouring mangrove habitats in subtropical South African estuaries. Salt marsh is another important habitat type that is commonly found in warm temperate South African estuaries and often contains Phragmites reeds, among other floral species. The stems of Phragmites spp. typically house a significant biomass of epiphytic algae (Karosienè and Kasperovičienė 2012), which offer an additional food source for fishes, while the reeds themselves offer refuge from predators. 
Additionally, all four estuaries sampled had a number of shallow mud and sand banks, both of which made large contributions to the overall percentage of CPUE of dominant species. It is thought that these shallow habitats could offer a refuge for young fishes that are vulnerable to predation. Paterson and Whitfield (2000) provide evidence that shallow portions of estuaries provide a refuge for small fishes, because shallow areas are often more turbid than deeper areas and are also typically inaccessible to larger piscivorous fishes. Sheaves et al. (2015) also noted that during an ebb tide submerged macrophytic vegetation can drain and become exposed, thus forcing small fishes into adjacent deeper water where the likelihood of encountering larger piscivorous fishes is greater.

Ultimately, estuaries with an availability of a variety of nursery habitat types are more beneficial to the survival of young fishes and are able to support a greater abundance and diversity of ichthyofauna than estuaries with low habitat complexity (Gratwicke and Speight 2005). Estuaries in South Africa offer a range of complex juvenile nursery habitats (Whitfield 2017). This habitat complexity, coupled with steep gradients of environmental variables (such as turbidity), may improve the recruitment and survival of larvae and juveniles within these systems and thus promote high species richness and diversity in comparison with estuarine systems that are near void of littoral vegetation (Gratwicke and Speight 2005, Whitfield 2017).

Although no significant differences in abundance and diversity were found between mangrove and non-mangrove estuaries in the study, it is important to not write off mangroves as significant refuge and habitat providers in warm temperate regions. The loss of habitat provided by mangroves has been found to significantly reduce the abundance and diversity of ichthyofaunal assemblages, which could potentially have cascading effects at higher trophic levels, leading to severe consequences for fisheries and food production (Manson et al. 2005, Aburto-Oropeza et al. 2008). In the present study, fish abundance and diversity was spread across a range of habitats, including mangroves. The loss of mangroves in warm temperate regions would therefore still have significant impacts for fishes utilizing estuaries. Mangroves are at the edge of their distributional range in warm temperate regions, and as a result cover less area than their counterparts in tropical and subtropical areas (Stevens et al. 2006). Warm temperate ichthyofauna have thus not yet needed to evolve a dependence on mangroves and their services, because other estuarine habitats offer similar refuge and feeding advantages. Furthermore, food is the limiting factor in seasonally mediated ecosystems (Short et al. 1990), making specific niche use a limitation in the broader foraging regimes typical of many marine fishes using estuaries.

The present study provides preliminary insights into the use of warm temperate mangroves by small fishes. In the event of future studies, it is suggested that a greater number of warm temperate mangrove estuaries be sampled to provide a larger database to assess the importance of mangroves in warm temperate regions in greater depth. Knowledge on the function of habitats and their role in enhancing fish survival in estuarine nursery areas is a crucial asset for fish conservation.

\section{ACKNOWLEDGEMENTS}

The authors extend their thanks to Eugin Bornman for imparting his statistical knowledge, and to Cuen Muller, Eugin Bornman, Kyle Hewett and Taryn Smit, who assisted with data collection and fieldwork. Thanks are also given to the Nelson Mandela University for providing infrastructural support and equipment for the duration of this study.

\section{REFERENCES}

Aburto-Oropeza O., Ezcurra E., Danemann G., et al. 2008. Mangroves in the Gulf of California increase fishery yields. Proc. Natl. Acad. Sci. U.S.A. 105: 10456-10459. https://doi.org/10.1073/pnas.0804601105

Adams J., Colloty B., Bate G. 2004. The distribution and state of mangroves along the coast of Transkei, Eastern Cape Province, South Africa. Wetlands Ecol. Manage. 12: 531-541. https://doi.org/10.1007/s11273-005-5165-0

Alongi D.M. 2002. Present state and future of the world's mangrove forests. Environ. Conserv. 29: 331-349. https://doi.org/10.1017/S0376892902000231

Beck M.W., Heck K.L., Able K.W., et al. 2001. The identification, conservation, and management of estuarine and marine nurseries for fish and invertebrates: A better understanding of the habitats that serve as nurseries for marine species and the factors that create site-specific variability in nursery quality will improve conservation and management of these areas. BioScience 51: 633-641.

https://doi.org/10.1641/0006-3568(2001)051[0633:TICAMO] 2.0.CO;2

Blaber S.J.M. 2007. Mangroves and fishes: Issues of diversity, dependence, and dogma. Bull. Mar. Sci. 80: 457-472.

Cameron A.C., Trivedi P.K. 1990. Regression-based tests for overdispersion in the Poisson model. J. Econometrics 46: 347-364. https://doi.org/10.1016/0304-4076(90)90014-K

Clarke K.R., Gorley R.M. 2006. PRIMER v6. PRIMER-E Ltd. Plymouth, UK.

Duarte C.M., Cebrian J. 1996. The fate of marine autotrophic production. Limnol. Oceanogr. 41: 1758-1766. https://doi.org/10.4319/lo.1996.41.8.1758

Duke N.C. 1993. Mangrove floristics and biogeography. Am. Geophys. Union, Washington D.C.

Ellison A.M., Farnsworth E.J. 1992. The ecology of Belizean mangrove-root fouling communities: patterns of epibiont distribution and abundance, and effects on root growth. Hydrobiologia 247: 87-98. https://doi.org/10.1007/BF00008207

FAO. 2004. The state of world fisheries and aquaculture (SOFIA). FAO, Rome.

Gilman E.L., Ellison J., Duke N.C., et al. 2008. Threats to mangroves from climate change and adaptation options: A review. Aquat. Bot. 89: 237-250. https://doi.org/10.1016/j.aquabot.2007.12.009

Gratwicke B., Speight M. 2005. The relationship between fish species richness, abundance and habitat complexity in a range of shallow tropical marine habitats. J. Fish Biol. 66: 650-667. https://doi.org/10.1111/j.0022-1112.2005.00629.x

Hogarth P.J. 2015. The biology of mangroves and seagrasses. Oxford Univ. Press, Oxford. https://doi.org/10.1093/acprof:oso/9780198716549.001.0001

Hoppe-Speer S.C., Adams J.B., Rajkaran A. 2015. Mangrove expansion and population structure at a planted site, East London, South Africa. South. Forests 77: 131-139.

Karosienè J., Kasperovičienė J. 2012. Peculiarities of epiphyton algal communities formation on different macrophyte species. Bot. Lithuanica 18: 154-163. https://doi.org/10.2478/v10279-012-0017-3

Kathiresan K. 2008. Threats to mangroves. Annamalai Univ., Cent. Adv. Study Mar. Biol., India, pp. 476-483. 
Kristensen E., Bouillon S., Dittmar T., et al. 2008. Organic carbon dynamics in mangrove ecosystems: A review. Aquat. Bot. 89: 201-219. https://doi.org/10.1016/j.aquabot.2007.12.005

Laegdsgaard P., Johnson C.R. 1995. Mangrove habitats as nurseries: Unique assemblages of juvenile fish in subtropical mangroves in eastern Australia. Mar. Ecol. Prog. Ser. 126: 67-81. https://doi.org/10.3354/meps126067

Laegdsgaard P., Johnson C. 2001. Why do juvenile fish utilise mangrove habitats? J. Exp. Mar. Biol. Ecol. 257: 229-253. https://doi.org/10.1016/S0022-0981(00)00331-2

Lenanton R., Potter I. 1987. Contribution of estuaries to commercial fisheries in temperate Western Australia and the concept of estuarine dependence. Estuaries 10: 28. https://doi.org/10.2307/1352022

Lugendo B.R., Pronker A., Cornelissen I., et al. 2005. Habitat utilisation by juveniles of commercially important fish species in a marine embayment in Zanzibar, Tanzania. Aquat. Living Resour. 18: 149-158. https://doi.org/10.1051/alr:2005016

Macnae W. 1963. Mangrove swamps in South Africa. J. Ecol. 51: $1-25$. https://doi.org/10.2307/2257502

Mahesh R., Saravanakumar A. 2015. Temporal and spatial variability of fin fish assemblage structure in relation to their environmental parameters in Pichavaram mangrove ecosystem, India. Indian J. Mar. Sci. 44: 910-923

Manson F.J., Loneragan N.R., Skilleter G.A., et al. 2005. An evaluation of the evidence for linkages between mangroves and fisheries: A synthesis of the literature and identification of research directions. Oceanogr. Mar. Biol. 43: 483

Mumby P.J., Edwards A.J., Arias-González J.E. et al. 2004. Mangroves enhance the biomass of coral reef fish communities in the Caribbean. Nature 427: 533-536. https://doi.org/10.1038/nature02286

Nagelkerken I., Kleijnen S., Klop T., et al. 2001. Dependence of Caribbean reef fishes on mangroves and seagrass beds as nursery habitats: A comparison of fish faunas between bays with and without mangroves/seagrass beds. Mar. Ecol. Prog. Ser. 214: $225-235$ https://doi.org/10.3354/meps214225

Nagelkerken I., Roberts C., Van Der Velde G., et al. 2002. How important are mangroves and seagrass beds for coral-reef fish? The nursery hypothesis tested on an island scale. Mar. Ecol. Prog. Ser. 244: 299-305. https://doi.org/10.3354/meps244299

Nagelkerken I., Blaber S., Bouillon S., et al. 2008. The habitat function of mangroves for terrestrial and marine fauna: A review. Aquat. Bot. 89: 155-185. https://doi.org/10.1016/j.aquabot.2007.12.007

Naylor R.L., Goldburg R.J., Primavera J.H., et al. 2000. Effect of aquaculture on world fish supplies. Nature 405: 1017-1024. https://doi.org/10.1038/35016500

Oksanen J., Blanchet F.G., Friendly M., et al. 2017. VEGAN: Community Ecology Package. R package version 2.4-4.

Paterson A., Whitfield A. 1997. A stable carbon isotope study of the food-web in a freshwater-deprived South African estuary, with particular emphasis on the ichthyofauna. Est. Coast. Shelf Sci. 45: 705-715 https://doi.org/10.1006/ecss.1997.0243

Paterson A., Whitfield A. 2000. Do shallow-water habitats function as refugia for juvenile fishes? Est. Coast. Shelf Sci. 51: 359-364. https://doi.org/10.1006/ecss.2000.0640

Pattrick P., Strydom N. 2014. Recruitment of fish larvae and juveniles into two estuarine nursery areas with evidence of ebb tide use. Est. Coast. Shelf Sci. 149: 120-132. https://doi.org/10.1016/j.ecss.2014.08.003

Potter I.C., Tweedley J.R., Elliott M., et al. 2015. The ways in which fish use estuaries: A refinement and expansion of the guild approach. Fish Fish. 16: 230-239. https://doi.org/10.1111/faf.12050

Quisthoudt K., Adams J., Rajkaran A., et al. 2013. Disentangling the effects of global climate and regional land-use change on the current and future distribution of mangroves in South Africa. Biodivers. Conserv. 22: 1369-1390. https://doi.org/10.1007/s10531-013-0478-4

Robertson A., Duke N. 1987. Mangroves as nursery sites: Comparisons of the abundance and species composition of fish and crustaceans in mangroves and other nearshore habitats in tropical Australia. Mar. Biol. 96: 193-205. https://doi.org/10.1007/BF00427019

Rönnbäck P. 1999. The ecological basis for economic value of seafood production supported by mangrove ecosystems. Ecol. Econ. 29: 235-252.

https://doi.org/10.1016/S0921-8009(99)00016-6

Saintilan N., Wen L. 2012. Environmental predictors of estuarine fish landings along a temperate coastline. Est. Coast. Shelf Sci. 113: 221-230. https://doi.org/10.1016/j.ecss.2012.08.007

Saintilan N., Wilson N.C., Rogers K., et al. 2014. Mangrove expansion and salt marsh decline at mangrove poleward limits. Global Change Biol. 20: 147-157. https://doi.org/10.1111/gcb.12341

Sheaves M., Baker R., Nagelkerken I., et al. 2015. True value of estuarine and coastal nurseries for fish: Incorporating complexity and dynamics. Estuaries and Coasts 38: 401-414 https://doi.org/10.1007/s12237-014-9846-x

Short F., Dennison W., Capone D. 1990. Phosphorus-limited growth of the tropical seagrass Syringodium filiforme in carbonate sediments. Mar. Ecol. Prog. Ser. 60: 169-174. https://doi.org/10.3354/meps062169

Stevens P.W., Fox S.L., Montague C.L. 2006. The interplay between mangroves and saltmarshes at the transition between temperate and subtropical climate in Florida. Wetlands Ecol. Manage. 14: 435-444. https://doi.org/10.1007/s11273-006-0006-3

R Core Team. 2017. R: A language and environment for statistical computing. R Foundation for Statistical Computing, Vienna, Austria.

van der Elst R., Wallace J. 1976. Identification of the juvenile mullet of the east coast of South Africa. J. Fish Biol. 9: 371-374. https://doi.org/10.1111/j.1095-8649.1976.tb04685.x

Ward C., Steinke T.D. 1982. A note on the distribution and approximate areas of mangroves in South Africa. S. Afr. J. Bot. 1: $51-53$. https://doi.org/10.1016/S0022-4618(16)30176-0

Weerts S., Cyrus D. 2002. Occurrence of young and small-sized fishes in different habitats within a subtropical South African estuary and adjacent harbour. Mar. Freshw. Res. 53: 447-456. https://doi.org/10.1071/MF01155

Whitfield A.K. 1994a. Abundance of larval and 0+ juvenile marine fishes in the lower reaches of three southern African estuaries with differing freshwater inputs. Mar. Ecol. Prog. Ser. 105: 257-267. https://doi.org/10.3354/meps 105257

Whitfield A.K. 1994b. An estuary-association classification for the fishes of southern Africa. S. Afr. J. Sci. 90: 411-417.

Whitfield A.K. 2017. The role of seagrass meadows, mangrove forests, salt marshes and reed beds as nursery areas and food sources for fishes in estuaries. Rev. Fish Biol. Fish. 27: 75-110. https://doi.org/10.1007/s11160-016-9454-X

Whitfield A.K., Baliwe N. 2013. A century of science in South African estuaries: Bibliography and review of research trends. SANCOR Occasional Report No. 7: 289 pp.

Wickham H. 2009. ggplot2: Elegant Graphics for Data Analysis. Springer-Verlag, New York.

Wiseman K., Burns M., Vernon C. 1993. Report No. 42: Nahoon (CSE 44), Qinira (CSE 45) and Gqunube (CSE 46). In: Morant P.D. (ed.), Estuaries of the Cape. Part II. Synopses of available information on individual systems. CSIR Res. Rep. 441: 1-136.

Wood S.N., Pya N., Saefken B. 2016. Smoothing parameter and model selection for general smooth models (with discussion). J. Am. Stat. Assoc. 111: 1548-1575. https://doi.org/10.1080/01621459.2016.1180986 